
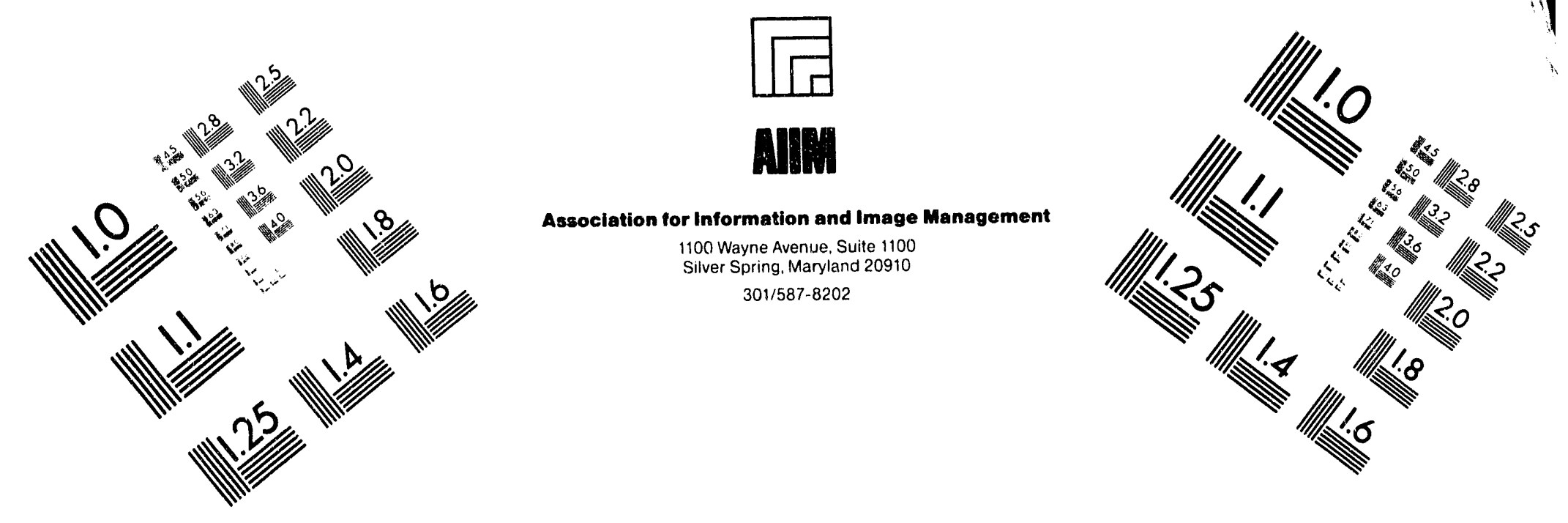

\title{
Centimeter
}

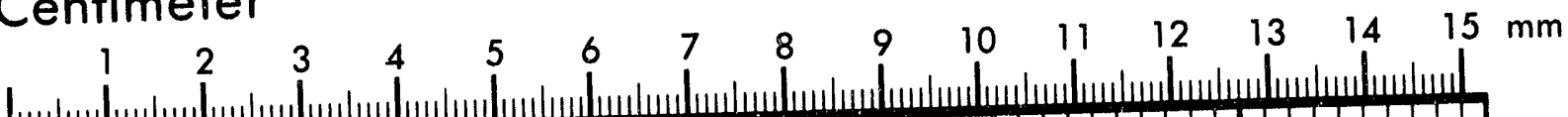

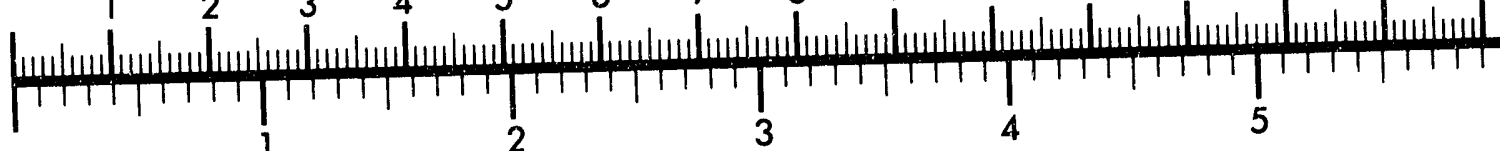

Inches


MANUFACTURED TO AIIM STANDARDS

BY APPLIED IMAGE, INC.

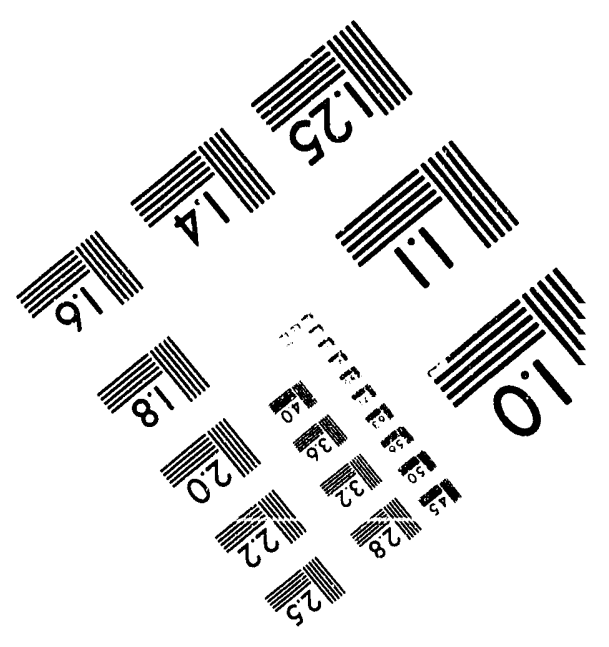



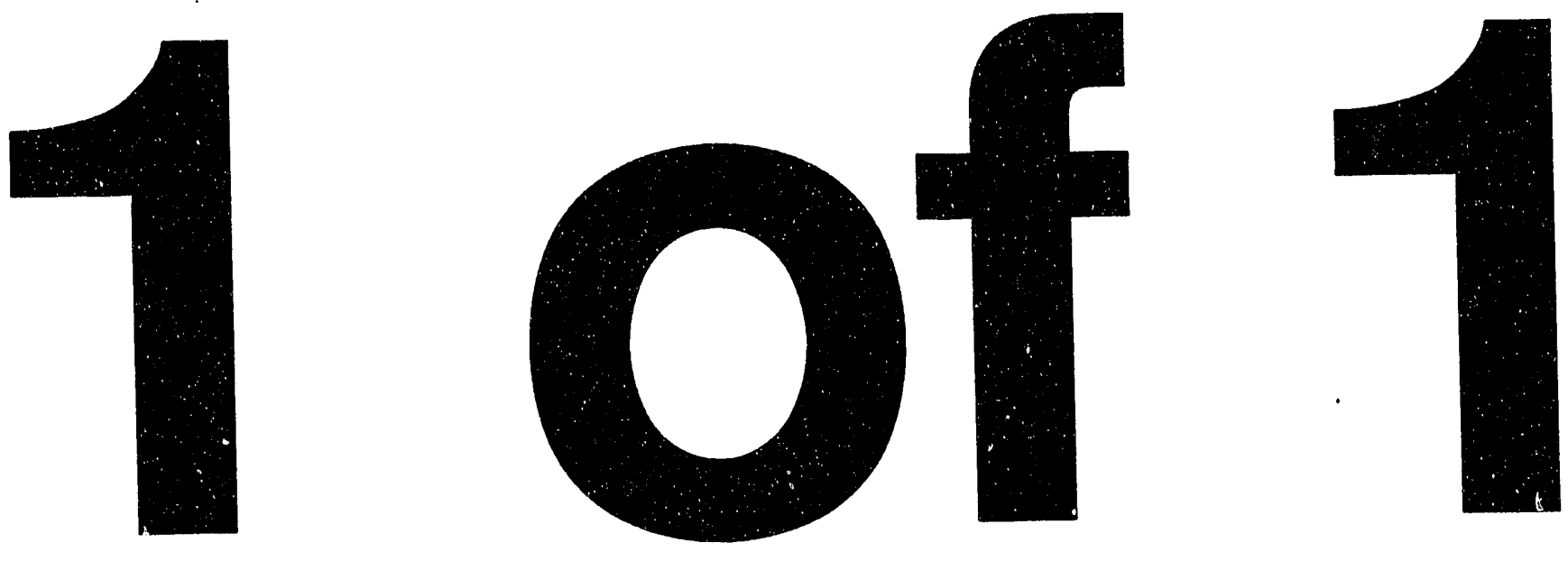


\section{LABORATORY SOLVENT REUSE - LIQUID CHROMATOGRAPHY}

W. Tim Quinlin

Clifford L. Schaffer

NOVEMBER 1992

Process Development

Waste and Hazard Minimization 


\title{
LABORATORY SOLVENT REUSE - LIQUID CHROMATOGRAPHY
}

\author{
W. Tim Quinlin
}

Clifford L. Schaffer

NOVEMBER 1992

\author{
Process Development \\ Waste and Hazard Minimization
}

\begin{abstract}
The objective of this work was to develop a method for reduction of waste solvent in the Process Engineering Chemistry Laboratory. The liquid chromatographs are the largest generators of explosive contaminated waste in the laboratory. We developed a successful process for the reuse of solvents from the liquid chromatographs and demonstrated the utility of the process in the assay of hexanitrostilbene.
\end{abstract}




\section{INTRODUCTION}

As part of the Waste Minimization Program in the Explosives Technology Division, we evaluated the solvent usage in the Process Engineering Chemistry Laboratory. The laboratory generated significant amounts of explosive-contaminated waste liquids. The liquid chromatographs (LC) in the laboratory were identified as the major source of the contaminated waste solvents. The most frequent use of the LC was the assay of sym-hexanitrostilbene (HNS).

We considered three options for reduction of the contaminated waste solvent. First, the waste solvent could be returned to the solvent feed vessel and reused directly. Second, the waste solvent could be passed through an in-line adsorber such as activated carbon. Third, the waste solvent could be isolated and purified by a process such as distillation prior to reuse. In this report we cover the work on the first two of the three options considered.

\section{RESULTS AND DISCUSSION}

Estimates of the generation of explosives-contaminated waste solvent indicates an annual value of about 310 liters. Of this volume approximately $80 \%$ arises from the LC operations. The assay of HNS was the single most frequently run LC analysis, and it therefore was the process examined.

A normal-phase LC method for the assay of HNS is presently used. The HNS sample is initially dissolved in acetonitrile to a concentration of $10 \mathrm{mg} / 40 \mathrm{ml}$ of acetonitrile. All injections are from a 20$\mu$ l loop. Each weighed sample is analyzed four times with a calibration standard run between each injection. The inobile phase flows at a rate of $2 \mathrm{ml} / \mathrm{minute}$ and consists of $55 \%$ heptane, $30 \% \mathrm{n}$ butylchloride, and $15 \%$ acetonitrile. The mobile-phase feed vessel is a 1-liter flask. The standard run time for a single sample is 15 minutes. This flow generates about 1 liter of waste solvent per 8 bours per chromatograph. Several liquid chromatographs are normally used each workday; they are frequently operated in the automatic mode overnight. The data presented in this report includes the assay for dipicrylethane (DPE), the major impurity found in HNS, and the assay of HNS.

\section{BASELINE SERIES}

For the LC solvent to be suitable for reuse, it must not cause the quality of the analysis to suffer. We initially ran a series of $\mathrm{IC}$ analysis without solvent reuse on a well-characterized sample to establish a baseline to compare with the solvent reuse results. When the standard method is used, all mobile-phase and injection solvents are considered waste. From one weighed portion of HNS in acetonitrile, seven replicate samples were prepared. The seven replicate samples were used to establish the baseline limits for precision and accuracy. Table I shows the analytical results of the baseline samples. These data show that for a standard HNS assay, a $95 \%$ confidence level $(P=0.05)$ of $0.53 \%$ can be expected. Similarly a precision of $0.30 \%$ resulted from the DPE analysis. The spread in the data for the HNS assayed was found to $0.53 \%$ and for DPE $0.31 \%$.

We considered three methods for the reuse of the mobile-phase system. Of the three, the least-desirable method was the operation of an external process (such as distillation) before solvent reuse. The demands of providing for distillation made the use of this process undesirable. The two alternative methods are direct solvent reuse without purification and reuse by activated carbon purification of the solvent. 


\begin{tabular}{||c|c|c|c|c|c||}
\hline \multicolumn{7}{|c|}{ Table I. Assay - No Solvent Reuse } \\
\hline \hline \% HNS & $\sigma$ & $\mathrm{P}=0.05$ & \% DPE & $\sigma$ & $\mathrm{P}=0.05$ \\
\hline 98.41 & 0.16 & 0.26 & 1.75 & 0.14 & 0.22 \\
98.53 & 0.28 & 0.70 & 1.45 & 0.15 & 0.24 \\
98.90 & 0.34 & 0.85 & 1.63 & 0.24 & 0.38 \\
98.84 & 0.14 & 0.22 & 1.45 & 0.14 & 0.22 \\
98.63 & 0.08 & 0.20 & 1.60 & 0.21 & 0.34 \\
98.94 & 0.36 & 0.90 & 1.44 & 0.23 & 0.37 \\
98.59 & 0.37 & 0.59 & 1.72 & 0.14 & 0.35 \\
\hline Avg. 98.69 & 0.25 & 0.53 & 1.58 & 0.18 & 0.30 \\
\hline
\end{tabular}

\section{DIRECT REUSE OF SOLVENT}

The simplest solution, although not necessarily the most effective quality-wise, is the reuse of the solvent without purification. The setup used for this experiment was the same as used for the baseline series except the waste stream was directed back to the feed/return vessel, and the feed/return vessel was 100 $\mathrm{ml}$ volume instead of the normal $1000 \mathrm{ml}$. We reduced the volume of the feed vessel in order to amplify by a factor of ten the effect of the unpurified solvent reuse. The injection order was the same as before, but the series of analysis was repeated four times using the untreated recycled solvent. We allowed an additional 8 minutes between injections to permit the baseline of the chromatogram to be re-established.

The data from the four series of runs, listed in Table Il, show that the assay values increase only slightly from one set to the next, but the precision decreases dramatically as indicated by the averages of the $95 \%$ confidence levels.

\section{SOLVENT REUSE WITH CARBON ADSORPTION COLUMN}

The procedure for the third series of assays made use of an activated carbon column in the mobile-phase loop. The column was filled with $4 \mathrm{~g}$ of Filtersorb 400 (Calgon). In this series no delay time was required for the chromatograph baseline to stabilize between injections. As with the direct reuse series, the receiver/feed vessel was $100-\mathrm{ml}$ capacity. The data from this series, summarized in Table III, show no loss in precision from one series to the next in contrast to the results in Table II. These data suggest that the carbon column prevented the steady decrease in precision that was shown in the direct reuse of the untreated solvent. A loss of precision with the carbon column series was indicated by comparing the HNS assay's average $95 \%$ confidence level of these runs, $1.58 \%$, with that of the baseline series average of $0.53 \%$. The difference is attributed to instrumental effects and/or the addition of the carbon column to the system. We made a second series of runs (Table IV) with the carbon column in place and with a more stable instrument baseline. In contrast to the previous series of runs, the data from the second series show that the carbon column does not cause a precision problem. The $95 \%$ confidence levels for the HNS assay, 0.62 and $0.55 \%$, are similar to the $0.53 \%$ for the baseline data. 


\begin{tabular}{|c|c|c|c|c|c|}
\hline \multicolumn{2}{|c|}{ Table II. } & \multicolumn{4}{|c|}{ Assay - Direct Reuse of Solvent } \\
\hline$\%$ HNS & $\sigma$ & $P=0.05$ & \% DPE & $\sigma$ & $P=0.05$ \\
\hline \multicolumn{6}{|c|}{ Series 1} \\
\hline $\begin{array}{l}98.40 \\
98.33 \\
98.82 \\
98.32 \\
98.19 \\
98.46 \\
98.47 \\
\end{array}$ & $\begin{array}{l}0.25 \\
0.80 \\
0.42 \\
0.45 \\
0.08 \\
0.09 \\
0.12 \\
\end{array}$ & $\begin{array}{l}0.40 \\
1.28 \\
0.67 \\
0.72 \\
0.20 \\
0.23 \\
0.19 \\
\end{array}$ & $\begin{array}{l}1.66 \\
1.66 \\
1.63 \\
1.64 \\
1.64 \\
1.65 \\
1.65 \\
\end{array}$ & $\begin{array}{l}0.05 \\
0.04 \\
0.04 \\
0.03 \\
0.02 \\
0.03 \\
0.04 \\
\end{array}$ & $\begin{array}{l}0.07 \\
0.06 \\
0.06 \\
0.05 \\
0.03 \\
0.04 \\
0.07 \\
\end{array}$ \\
\hline Avg. 98.43 & 0.32 & 0.53 & 1.65 & 0.03 & 0.05 \\
\hline \multicolumn{6}{|c|}{ Series 2} \\
\hline $\begin{array}{l}97.41 \\
98.91 \\
98.28 \\
99.00 \\
98.34 \\
98.04 \\
99.45 \\
\end{array}$ & $\begin{array}{l}1.64 \\
0.14 \\
1.38 \\
0.40 \\
1.26 \\
1.14 \\
0.70 \\
\end{array}$ & $\begin{array}{l}2.62 \\
0.35 \\
2.20 \\
0.64 \\
2.02 \\
1.83 \\
1.12 \\
\end{array}$ & $\begin{array}{l}1.62 \\
1.63 \\
1.66 \\
1.69 \\
1.62 \\
1.57 \\
1.67 \\
\end{array}$ & $\begin{array}{l}0.07 \\
0.05 \\
0.12 \\
0.02 \\
0.03 \\
0.07 \\
0.04 \\
\end{array}$ & $\begin{array}{l}0.11 \\
0.08 \\
0.19 \\
0.03 \\
0.05 \\
0.11 \\
0.06 \\
\end{array}$ \\
\hline Avg. 98.49 & 0.95 & 1.54 & 1.64 & 0.06 & 0.09 \\
\hline \multicolumn{6}{|c|}{ Series 3} \\
\hline $\begin{array}{l}98.52 \\
98.87 \\
98.28 \\
99.20 \\
97.64 \\
99.16 \\
97.97 \\
\end{array}$ & $\begin{array}{l}0.93 \\
1.20 \\
1.30 \\
0.83 \\
1.04 \\
0.95 \\
1.67 \\
\end{array}$ & $\begin{array}{l}1.49 \\
1.93 \\
2.09 \\
1.33 \\
1.66 \\
1.52 \\
2.67 \\
\end{array}$ & $\begin{array}{l}1.69 \\
1.74 \\
1.70 \\
1.64 \\
1.63 \\
1.63 \\
1.64 \\
\end{array}$ & $\begin{array}{l}0.05 \\
0.07 \\
0.07 \\
0.07 \\
0.05 \\
0.05 \\
0.12 \\
\end{array}$ & $\begin{array}{l}0.08 \\
0.11 \\
0.12 \\
0.11 \\
0.07 \\
0.08 \\
0.19 \\
\end{array}$ \\
\hline Avg. 98.52 & 1.13 & 1.81 & 1.67 & 0.07 & 0.11 \\
\hline \multicolumn{6}{|c|}{ Series 4} \\
\hline $\begin{array}{l}98.48 \\
97.97 \\
99.52 \\
98.42 \\
98.54 \\
98.27 \\
99.83\end{array}$ & $\begin{array}{l}2.17 \\
2.09 \\
1.62 \\
2.30 \\
2.01 \\
2.05 \\
0.56 \\
\end{array}$ & $\begin{array}{l}3.47 \\
3.35 \\
2.59 \\
3.68 \\
3.22 \\
3.29 \\
1.40 \\
\end{array}$ & $\begin{array}{l}1.69 \\
1.66 \\
1.67 \\
1.68 \\
1.61 \\
1.57 \\
1.72 \\
\end{array}$ & $\begin{array}{l}0.05 \\
0.01 \\
0.04 \\
0.12 \\
0.07 \\
0.10 \\
0.02 \\
\end{array}$ & $\begin{array}{l}0.09 \\
0.09 \\
0.07 \\
0.30 \\
0.18 \\
0.25 \\
0.18 \\
\end{array}$ \\
\hline Avg. 98.72 & 1.83 & 3.00 & 1.66 & 0.06 & 0.16 \\
\hline
\end{tabular}




\begin{tabular}{|c|c|c|c|c|c|c|c|c|c|c|}
\hline \multirow{7}{*}{ 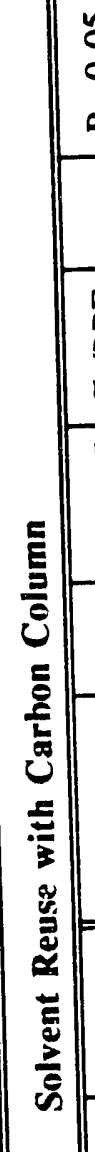 } & $\begin{array}{l}8 \\
0 \\
11 \\
0\end{array}$ & \multirow{6}{*}{ 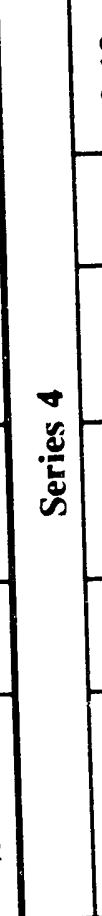 } & $\frac{O}{0} \frac{N}{0} \frac{9}{0} \frac{m}{0} \frac{0}{0} \frac{0}{0}$ & $\frac{n}{0}$ & \multirow{6}{*}{ 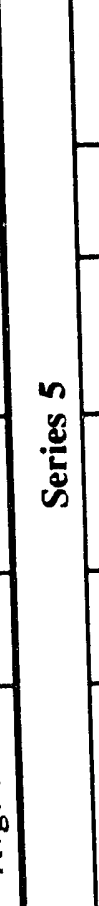 } & 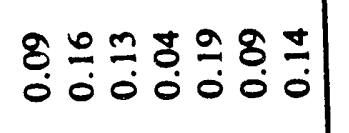 & $\frac{y}{0}$ & \multirow{6}{*}{ 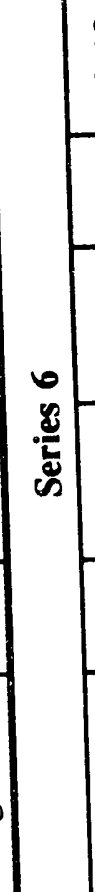 } & 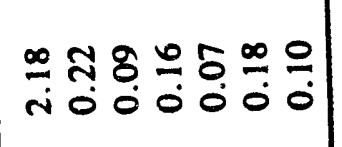 & $\begin{array}{l}m \\
\dot{q}\end{array}$ \\
\hline & 0 & & 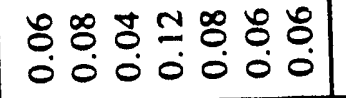 & $\begin{array}{l}5 \\
0 \\
0\end{array}$ & & 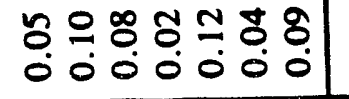 & $\begin{array}{l}5 \\
0 \\
0\end{array}$ & & 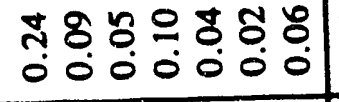 & $\begin{array}{l}8 \\
0\end{array}$ \\
\hline & $\begin{array}{l}\frac{1}{a} \\
\frac{1}{0} \\
08\end{array}$ & & 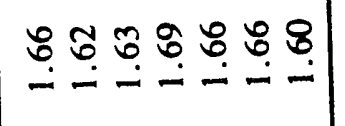 & 萬 & & 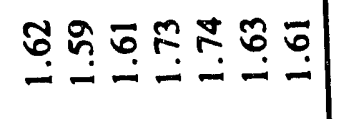 & $\ddot{n}$ & & 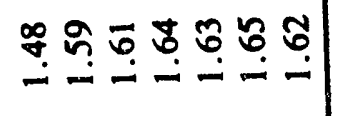 & $\begin{array}{l}8 \\
-\end{array}$ \\
\hline & $\begin{array}{l}0 \\
0 \\
0 \\
11 \\
0 .\end{array}$ & & 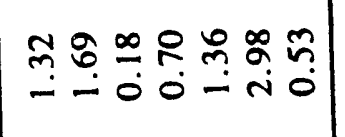 & $\stackrel{\sim}{\mathfrak{n}}$ & & 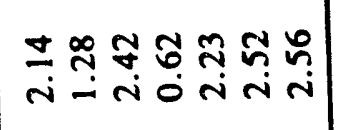 & $\underline{-}$ & & 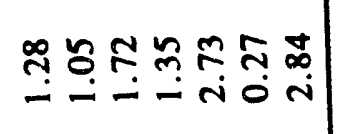 & $\stackrel{8}{-}$ \\
\hline & 0 & & 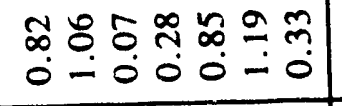 & $\begin{array}{l}: \\
: \\
0\end{array}$ & & 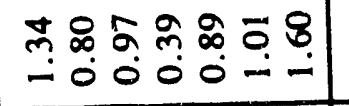 & $\stackrel{8}{-}$ & & 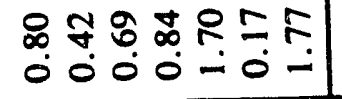 & $\bar{a}$ \\
\hline & $\begin{array}{l}\frac{n}{Z} \\
\frac{1}{1} \\
0\end{array}$ & & 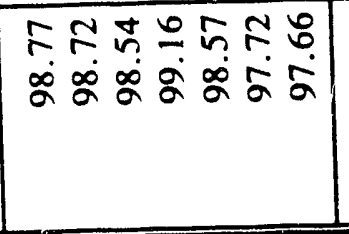 & $\begin{array}{l}\qquad \\
y \\
\infty \\
a \\
\dot{0} \\
z \\
z\end{array}$ & & 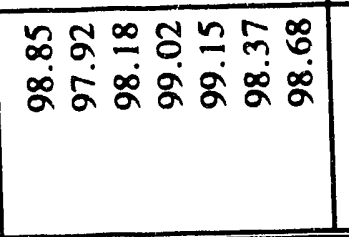 & 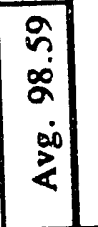 & & 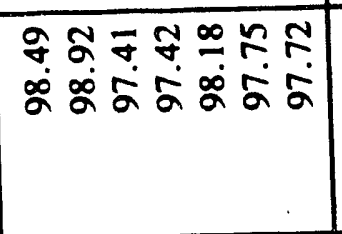 & $\begin{array}{c}\infty \\
5 \\
5 \\
\dot{0} \\
z \\
z\end{array}$ \\
\hline & $\begin{array}{l}n \\
0 \\
0 \\
11 \\
2\end{array}$ & & $\frac{a}{0} \frac{n}{0} \frac{m}{0}=\frac{n}{0} \frac{n}{0}$ & $\frac{m}{0}$ & & 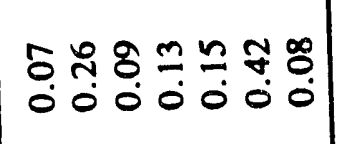 & $\frac{5}{0}$ & & 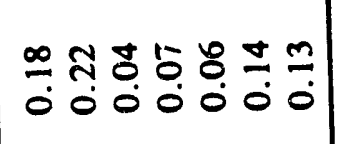 & $\frac{N}{0}$ \\
\hline . & 0 & & 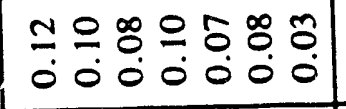 & $\begin{array}{l}\infty \\
0 \\
0\end{array}$ & & 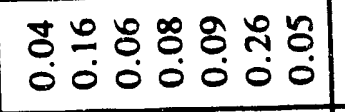 & $=$ & & 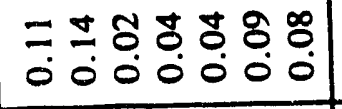 & 5 \\
\hline 总 & $\begin{array}{l}\frac{1}{2} \\
\frac{0}{0} \\
\text { se }\end{array}$ & -1 & 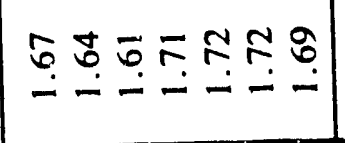 & $\stackrel{\infty}{\infty}$ & $N$ & 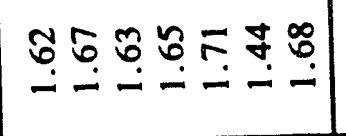 & $\stackrel{\oplus 0}{-}$ & $m$ & 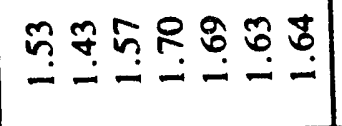 & $\stackrel{8}{-}$ \\
\hline & $\begin{array}{l}2 \\
0 \\
0 \\
11 \\
0\end{array}$ & 离 & 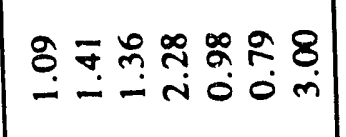 & $\stackrel{n}{n}$ & 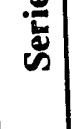 & 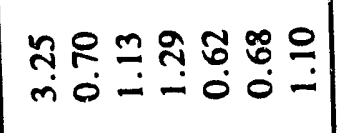 & $\stackrel{n}{-}$ & ฝั & 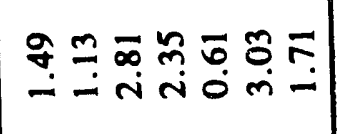 & $\stackrel{\infty}{\infty}$ \\
\hline & 0 & & 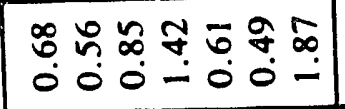 & $\hat{a}$ & & 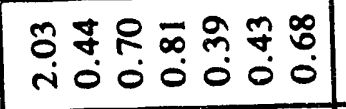 & $\stackrel{\infty}{0}$ & & 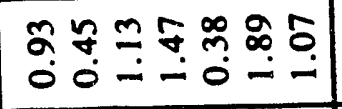 & $\stackrel{n}{-}$ \\
\hline & $\begin{array}{l}\text { za } \\
\text { Z⿱ } \\
\text { ve } \\
0\end{array}$ & & 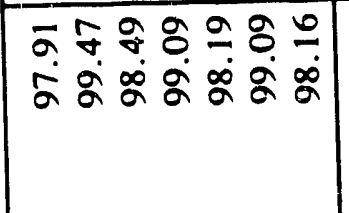 & $\begin{array}{l}\hat{6} \\
0 \\
0 \\
0 \\
0 \\
2\end{array}$ & & 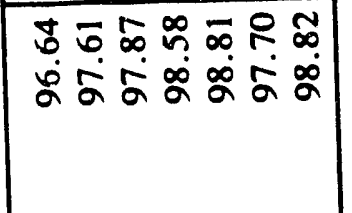 & $\begin{array}{c}8 \\
\infty \\
0 \\
0 \\
\dot{0} \\
20 \\
\gtrless\end{array}$ & & 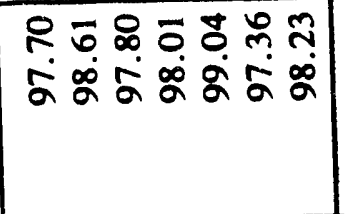 & $\begin{array}{l}= \\
\ddot{\alpha} \\
\dot{\alpha}\end{array}$ \\
\hline
\end{tabular}




\begin{tabular}{|c|c|c|c|c|c|}
\hline \multicolumn{6}{|c|}{$\begin{array}{cc}\text { Table IV. Solvent Reuse with Carbon Column } \\
\text { (Short Series) }\end{array}$} \\
\hline$\%$ HNS & $\sigma$ & $P=0.05$ & \% DPE & $\sigma$ & $P=0.05$ \\
\hline \multicolumn{6}{|c|}{ Series 1} \\
\hline $\begin{array}{l}98.99 \\
98.40 \\
98.25 \\
98.52 \\
98.59 \\
98.58 \\
98.55 \\
\end{array}$ & $\begin{array}{l}0.25 \\
0.40 \\
0.32 \\
0.25 \\
0.35 \\
0.19 \\
0.34 \\
\end{array}$ & $\begin{array}{l}0.40 \\
0.64 \\
0.51 \\
0.63 \\
0.89 \\
0.47 \\
0.84 \\
\end{array}$ & $\begin{array}{l}1.67 \\
1.67 \\
1.64 \\
1.64 \\
1.62 \\
1.65 \\
1.61 \\
\end{array}$ & $\begin{array}{l}0.06 \\
0.03 \\
0.02 \\
0.05 \\
0.01 \\
0.03 \\
0.06 \\
\end{array}$ & $\begin{array}{l}0.10 \\
0.05 \\
0.03 \\
0.08 \\
0.02 \\
0.05 \\
0.10 \\
\end{array}$ \\
\hline Avg. 98.56 & 0.30 & 0.62 & 1.64 & 0.04 & 0.06 \\
\hline \multicolumn{6}{|c|}{ Series 2} \\
\hline $\begin{array}{l}98.50 \\
98.66 \\
98.71 \\
99.05 \\
98.63 \\
98.74 \\
98.60 \\
\end{array}$ & $\begin{array}{l}0.15 \\
0.28 \\
0.19 \\
0.91 \\
0.36 \\
0.06 \\
0.35 \\
\end{array}$ & $\begin{array}{l}0.25 \\
0.45 \\
0.48 \\
1.46 \\
0.57 \\
0.10 \\
0.56 \\
\end{array}$ & $\begin{array}{l}1.63 \\
1.67 \\
1.59 \\
1.65 \\
1.69 \\
1.67 \\
1.64 \\
\end{array}$ & $\begin{array}{l}0.03 \\
0.05 \\
0.04 \\
0.04 \\
0.01 \\
0.04 \\
0.03 \\
\end{array}$ & $\begin{array}{l}0.06 \\
0.07 \\
0.06 \\
0.06 \\
0.03 \\
0.07 \\
0.04 \\
\end{array}$ \\
\hline Avg. 98.70 & 0.33 & 0.55 & 1.65 & 0.03 & 0.06 \\
\hline
\end{tabular}

\section{CONCLUSION}

In today's environmental climate the reduction in solvent usage, even when the quantity is small, is profitable from both the cost savings associated with the purchase of the solvent and even more so from the cost involved with its disposal. The disposal costs are significantly increased when the solvent is contaminated with explosives such as the LC solvents from the laboratory.

The use of in-line carbon columns to remove traces of explosive contaminants from LC solvents is inexpensive, easy to install, and yields high-quality analytical results. As the data show, a series of HNS samples and calibration standards involving 336 chromatographic injections can yield quality results with no observable degradation to the solvent system. The use of an in-line carbon column should be applicable to other LC analyses involving other explosives as well as to a variety of other non-explosive materials.

\section{ACKNOWLEDGMENT}

The careful work of D. M. Cates in the sample preparation and operation of the LC is greatly appreciated. 


\section{DISTRIBUTION}

DEPARTMENT OF ENERGY - WASHINGTON, DC

Director of Weapons Production

Office of Military Application

\section{DEPARTMENT OF ENERGY - AL}

Technical Information Officer, IPS

Quality Operations Branch

Weapons Quality Division

Technology Development Branch

Weapons Quality Division

Waste Management Branch

Waste Management and

Operational Surety Division

Program Support Branch

Weapon Programs Division

DEPARTMENT OF ENERGY - AAO

Area Manager

OFFICE OF SCIENTIFIC AND TECHNICAL INFORMATION - OAK RIDGE. TN

(62)

LAWRENCE LIVERMORE NATIONAL LABORATORY

L-32

L-53

L-125

L-281

L-282 (6)

L-394

\section{LOS ALAMOS NATIONAL LABORATORY}

M-1 (3)

M-7

M-DO

WX-1

WX-3 Group Office

WX-DO

ISD-4
SANDIA NATIONAL LABORATORIES - ALBUQUEROUE

Org. 300

Org. 2361

Org. 2512

Org. 5100

\section{SANDIA NATIONAL LABORATORIES - LIVERMORE}

Org. 8133

EG\&G MOUND APPLIED TECHNOLOGIES

Manager, Product and Process Development

\section{SAVANNAH RIVER LABORATORY}

Program Manager, Defense Waste Processing Section, 773-A

ALLIED-SIGNAL INC. - KANSAS CITY PLANT

Material Engineering

MASON \& HANGER - PANTEX PLANT

\author{
Production and Operations Directorate \\ Engineering and Design Division \\ ES\&H/WM Directorate \\ Explosives Technology Division (6) \\ Manufacturing Division \\ Program Management Division \\ Quality Division \\ Circulation Copy: \\ 1. R. M. Loghry, 12-6 \\ 2. C. D. Alley, 12-36 \\ 3. B. D. Faubion, 11-2 \\ Technical Library \\ File (5)
}

Please refer any distribution changes to

A. V. Lucero, Publications Section FTS 477-3535. 

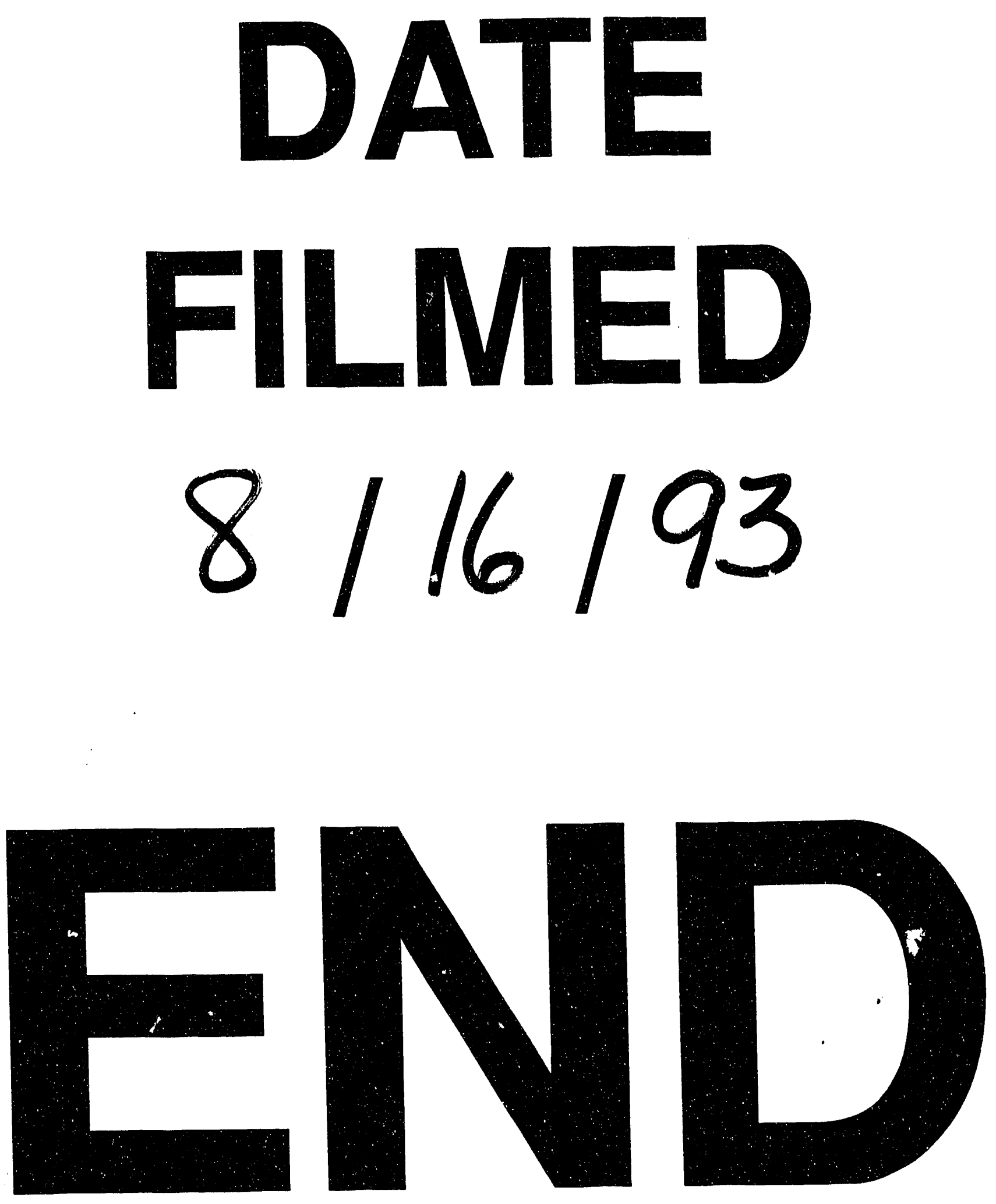
